\title{
Investigating the Factors Affecting Grocery Sales in Itahari, Nepal
}

\author{
Arjun Rai \\ Lecturer \\ Faculty of Management \\ Mahendra Multiple Campus, Dharan, TU, Nepal \\ chhiwatpang@gmail.com
}

\begin{abstract}
This paper attempts to investigate the viability of small scaled grocery shops located in Itahari, Nepal. For this purpose, primary data have been collected from different 39 grocery stores using structured questionnaire. The collected data has been analyzed by using SPSS-20. The research method includes both descriptive and inferential statistics for the analysis. The finding of the study shows that the average daily sales are significantly affected by the amount of capital in positive way. Similarly, the study revealed that the average daily sales are positively affected by the age of shop; but in a statistically insignificant way.

Keywords: grocery shops, kirana-pashal, sales revenue, capital, sales models, purchase models.
\end{abstract}

\section{Introduction}

\subsection{Background}

Kathmandu Post, a national daily on its issue of January 20, 2018 published an article 'As traditional retail shops flounder, department stores thrives in East' by B.R. Paudel claims that at a time when traditional retail stores are floundering, department stores have emerged as the shoppers choice in the eastern region; and so their business is booming. A large number of department stores have come into operation in various urban centers of Province No 1; and their customer numbers are increasing daily. But couples of decades back the context was different; different in the sense that majority of consumers used to buy their sundries or grocery items from small family owned grocery stores. Although many supermarkets are opening up, still many customers are new to the concept of shopping in department stores. Still large urban and rural consumers' daily necessities are met by small grocery shops located nearby consumers' residence.

But with the advent of information communication technology and digital marketing, traditional retail marketing is witnessing a paradigm shift in terms of shopping habits of customers. Specially, the developed economies have started witnessing the fall in sales of small scale grocery shops. Kuijpers, Simmons, and Wamelen, (2018), asserted that $\$ 5.7$ trillion global grocery industry is in trouble. Although it has grown at about 4.5 percent annually over 
the past decade, that growth has been highly uneven-and has masked deeper problems. This phenomenon is compounding in Nepalese context as well.

Despite the fact that new online shops have been emerging, few retail companies such as Bhatbhateni, Gorkha Department store are aggressively opening up their new outlets, new corner stores, or grocery shops or typically 'Kirana Pasal' are being established in urban and rural areas. Meanwhile, many online grocery shops are emerging in Nepal, such as 'mero kirana' and 'mero tarkari', and online grocery shops are witnessing rapid growth in their business. Quoting an article by Krishna Prasain, published in the national daily 'Kathmandu post.com' on $4^{\text {th }}$ March, 2019, in the article, the writer quoting the founder Anil Basnet states that Metro Tarkari, a popular online vegetable service provider, has been making 10 percent monthly growth. Further, the article mentions that 'merotarkari.com' was able to make 100 percent growth annually. In the context of large organized retail giants like Bhatbhateni, Gorkha Department stores are aggressively making their presence in the market and other digital entrepreneurs are starting up online grocery stores, this article attempts to explore the viability, profitability of brick and mortar concept of grocery shops located in Itahari, a sub metropolitan city of Province Number 1. Research Problem: Karna, Rai, Karki, Karna, Rai, \& Adhikari, (2019), state that it has been observed that departmental stores are no longer the only stores providing such services to the public and own no autonomy in the market like some decades ago. There have been Superstores and Shopping Malls and Marts. In Nepal's context itself, rise of such services have seen a major upliftment in the past decade. Bhatbhateni, established in a number of places within the nation, has emerged as a dominant place in the case of shopping in Nepal, (p. 384). Apart from, Bhatbhateni, in Eastern Nepal, in Province No. 1, Gorkha Department, and other retail stores are extending their branches. But still many grocery shops are coming into existence. Empirically it can be seen that grocery shops are becoming a means of self employment to many people, especially those who return from overseas employment, and people with low capital investment.

\subsection{Research problems}

This study attempts to answer the following research questions:

a What are the factors that affect the grocery sales?

b Does average daily sales revenue depend upon the size of capital?

c Does average daily sale revenue depend upon the age of business?

d Is there significant relation between business ownership type and sales volume?

e Is there significant relation between duration of credit purchase and credit sales?

\subsection{Research Objectives}

Following are the specific research objectives of the paper: 
a) To find out whether average daily sales revenue depends upon the amount of raised capital.

b) To examine if average daily sales revenue depends upon the age of business.

c) To investigate into the relationship between business ownership type and sales volume.

d) To examine the relation between duration of credit purchase and credit sales.

\subsection{Research Hypothesis}

Research hypothesis is a conjectural statement which is tested with the help of appropriate tools to collect data. In other words, a research hypothesis is an assumption about research findings, which are tested upon the collection and, analysis of the data. The hypothesis may be true or false; it is be tested using different statistical tools. In this study, the researcher formulated the following null hypothesis:

$\mathrm{H}_{1}$ : The sales revenue depends upon the raised capital.

Priori hypothesis: $A D S R=a+b_{1} \times C R$ (model to be tested)

Where, ADSR= Average Daily Sales Revenue,

$\mathrm{b}_{1=}$ beta coefficient of the independent variable 1 , and $\mathrm{CR}=$ Capital Raised)

$\mathrm{H}_{2}$ : The sale revenue depends upon the age of business

Priori hypothesis: Average Daily Sales Revenue $=a+b$ (age of business)

$\mathrm{H}_{3}$ : There is no significant relationship between duration of credit purchase and duration credit sales.

\subsection{Limitations of the Study}

Like other researches, even this research has certain limitations, in terms of scope, tools, and other analytical issues. This research has following limitations:

a This study comprised only the grocery shops located in Itahari, Nepal. The study could have been comprehensive, if similar stores from wider area were also included.

b Primarily this study used descriptive statistics and for analyzing the relationship between few variables the researcher used inferential statistics too. However, inferential purpose, other than descriptive statistics could have been used.

c Due to time limitations this study relied only on quantitative analysis of the data collected from grocery shops.

\subsection{Significance of Research}

This research article has the following significances:

i. This study will be useful to those who are aspiring to start their own grocery shops in near future. The findings such as; average required capital, highest selling season, duration of credit purchase and sales can be used as guidelines for formulating credit policies, arrangement of capital etc. 
ii. One of the objectives of this study is to find out the major cause of damage of merchandize in grocery shops. The findings reveal that the major cause of the damage of the goods is insects and pests. Considering this fact, the future and existing grocery shop owners can plan to mitigate such damage.

iii. Similarly, the finding of this study shows that, sales of such stores were high during the summer. Thus, this report may be used as a guideline for making inventory policies. It is advisable that grocery shop owners pile up their inventory level during summer.

\subsection{Literature Review}

Smallbusiness.chron.com (para. 2) defines grocery stores as the stores which specialize in the selling of food, both fresh and prepackaged, as well as nonfood household goods, such as paper towels, toilet paper, cleaning products and over-the-counter medicines. A typical grocery store sells fresh produce, meats, dairy products and, often, bakery goods alongside canned, frozen and prepared foods. In addition, a grocery store will also sell a full range of household, healthcare and personal care items. However, grocery shops in Nepal have different product assortment unlike as mentioned above. In Nepal such grocery shops are typical 'Kirana Pashal' which are generally family owned and, mostly offer sundries. educalingo.com, an online dictionary defines 'Kirana' as a small, usually family-owned shop selling groceries and other sundries.

Samriddhi, The Prosperity Foundation, defines 'Kirana Pasals' are mom-and-pop stores that sell groceries and other necessary daily goods, scattered around commercial hubs, serving the locals and the visitors alike with wide variety of goods, they are an integral part of the daily Nepali life. For the purpose of this research, 'Kirana Pasals' refer to micro or small enterprises that sell fast moving consumer goods, have basic infrastructure and use simple technology. The Industrial Enterprise Act, 1992 of Nepal characterizes such retail shops under Small Service Industries. Enterprises with fixed asset of value less than or equal to 30 million rupees are designated under Small Industries in this act.

Some of the factors taken into consideration for classifying enterprises are labour, turnover, initial investment and the net value of assets. Based on a certain limits set on these factors, enterprises are separated into micro, small, medium and large sized enterprises. There are many ways of defining these enterprises. However, there is no unanimity amongst the scholars with regards to universal factor to classify the enterprises. Various countries choose to define their MSMEs using one or more criteria. In the context of European Union, enterprises are classified into micro, small and medium sized enterprises based on their employment and turnover or net asset (EU, 2003). Japan classifies its enterprises based on initial investment and employment criteria's (The Government of Japan, 2013). In Nepal, the Industrial Enterprise Act 1992 (amended in 1997) categorizes Micro enterprises as those with fixed asset up to 200,000 rupees, small enterprises as those with fixed asset up to 30 million rupees, and medium 
enterprises as those with fixed asset between 30-100 million rupees. In this research 'Kirana Pasals' connotes micro and small enterprises definition in Nepali legislation.

\subsection{Research Gap}

Although many research works related to grocery shops are found in the literature, very few studies are found in the Nepalese context. This research related to grocery shops in the context of Nepal will fill that research gap.

\section{Methods \& Materials}

This research is descriptive in nature. A structured questionnaire was administered to collect primary data from 39 grocery store owners from Itahari, Nepal. In this research, the researcher's philosophical stance is positivist. The researcher used quantitative data analysis. Neuman (2010), asserts that quantitative technique has the ability to provide rigorous and precise measures. For analyzing the primary data, Statistical Package for Social Science -20 was used. This study used both descriptive and inferential statistics. In this study, Goodness of Fit and Chi-Square Tests were used for inference.

\section{Results and Discussion}

The following results have been shown and discussions were made to explain the research problems:

\section{Table 1}

Year of establishment of the store

\begin{tabular}{ccc}
\hline Year of establishment of business & Frequency & Valid percent \\
\hline Started business before 2045 & 1 & 2.6 \\
Between 2046-2060 & 7 & 17.9 \\
Between 2061-2075 & 30 & 76.9 \\
After 76 & 1 & 2.6 \\
Total & 39 & 100 \\
\hline
\end{tabular}

Table 1 shows year of establishment of grocery shops under the study. Out of 39 grocery shops located in Itahari, Nepal, 76.9\% stores were established in between 2061-2075 (Bikram Sambat, Nepali Calendar Year, hereinafter referred as B.S.), followed by the next highest number $17.9 \%$ of stores established in between 2046-2060 B.S. The least number of grocery shops established before 2045 B.S and after 2076 B.S is 1 , which is $2.6 \%$. Surge in the number of grocery shops during 2061 and 2075 B.S. might be as a result of peace process of 
decade long Maoist insurgency which assured a sense of peace and stability in the business community.

Table 2

Raised capital

\begin{tabular}{lll}
\hline Capital in (NRs.) & Frequency & Valid percent \\
\hline Capital 20 lakhs or below & 38 & 97.4 \\
Cap Above 40 lakhs & 1 & 2.6 \\
\hline Total & 39 & 100
\end{tabular}

Table 2 presents the amount of capital invested the grocery shops under the investigation. The table shows that out of 39 grocery shops 38 such stores i.e. $97.4 \%$ of the stores' capital is 20 lakhs or below and 1 store has capital of more than NRs. 40 lakhs.

Table 3

Daily average sales in (NRs.)

\begin{tabular}{lll}
\hline Daily average sales in (NRs.) & Frequency & Valid percent \\
\hline Sales Below 5000 & 21 & 53.8 \\
Sales Between 5000-10000 & 9 & 23.1 \\
Sales More than 10000 & 9 & 23.1 \\
\hline Total & 39 & 100 \\
\hline
\end{tabular}

Table 3 presents the average daily sales of the grocery shops. Out of 39 stores, $53.8 \%$ stores' average daily sales are less or equal to NRs. 5000 . But the $23.1 \%$ of grocery shops' average daily sales is in the range of NRs. 5000-10000 or more than NRs. 10000

Table 4

Business ownership type

\begin{tabular}{lll}
\hline Business ownership type & Frequency & Valid percent \\
\hline Family owned business & 1 & 2.6 \\
Self owned business & 38 & 97.4 \\
\hline Total & 39 & 100 \\
\hline
\end{tabular}

The table 4 tabulates the type of ownership of grocery shops. The table shows that out of 39 grocery shops $97.4 \%$ of the shops are self owned or the business started by the persons themselves. Only 1 store, i.e. $2.6 \%$ of the shop is family inherited business. Such low rate of family inherited business may be due to lack of entrepreneurial attitude of Nepalese society. However, until the research is conducted to examine this assertion, this statement cannot be established. 
Table 5

Mode of sales

\begin{tabular}{lll}
\hline Mode of sales & Frequency & Valid percent \\
\hline Cash & 11 & 28.2 \\
Credit & 1 & 2.6 \\
Both & 27 & 69.2 \\
\hline Total & 39 & 100 \\
\hline
\end{tabular}

Table 5 shows the mode of sales of the 39 grocery shops. Out of 39 grocery shops, $69.2 \%$ sell the goods in both cash and credit. Whereas; $28.2 \%$ stores sales mode is on cash. Those grocery shops selling the goods on credit modes stand at $2.6 \%$. The given figures represent the trends of sales. Since, the majority of the grocery shops sell on both cash and credit, anyone willing to start grocery shops in the given location may consider this fact.

Table 6

Percentage of bad debt loss

\begin{tabular}{lll}
\hline Bad debt loss percentage & Frequency & Valid percent \\
\hline bellow 5\% & 37 & 94.9 \\
$5-10 \%$ & 2 & 5.1 \\
\hline Total & 39 & 100 \\
\hline
\end{tabular}

Table 6 depicts the percentage of bad debt loss of the grocery shops. Out of 39 such stores, only 2 stores' bad loss percentage is in between 5-10\%. Other 37 grocery shops bad debt loss rate is below $5 \%$. Referring to table 5 , out of 39 stores, $28.2 \%$ grocery shops' sales mode is "cash" and $69.2 \%$ stores sell the goods on cash and credit basis. It can be hypothesized that out of $69.2 \%$ stores majority of their sales mode is on cash. Perhaps due to this reason, the bad debt loss of $94.9 \%$ grocery shops' bad debt loss is below $5 \%$.

Table 7

Season-wise volume of sales

\begin{tabular}{lll}
\hline High sales season & Frequency & Valid percent \\
\hline Summer & 28 & 71.8 \\
Winter & 6 & 15.4 \\
Spring & 2 & 5.1 \\
All & 3 & 7.7 \\
\hline Total & 39 & 100 \\
\hline
\end{tabular}


Table 7 presents the volume of sales during different seasons. Out of 39 grocery shops $71.8 \%$ grocery shops stated that their sales volumes are high during the summer season, followed by the next highest number $15.4 \%$ stores stating that sales volume are high during the winter seasons. Sales volumes are high in all seasons; such claims are made by $7.7 \%$ of grocery shops. The high sales during summer possibly can be attributed to the fact that majority of the festivals fall in summer. Or such high sales during summer may be because of longer days in summer. During summer the Sun sets very late enabling people to shop at late hours too.

Table 8

Duration of credit sales

\begin{tabular}{lll}
\hline Duration of credit sales & Frequency & Valid percent \\
\hline 0-10days & 28 & 71.8 \\
11-30days & 8 & 20.5 \\
more than 30 days & 3 & 7.7 \\
\hline Total & 39 & 100 \\
\hline
\end{tabular}

Table 8 exhibits the duration of credit sales of grocery shops located in Itahari, Nepal. Out of 39 grocery shops, 28 grocery shops' credit sales period is less or equal to 10 days. Similarly, 8 stores' credit sales duration is 11-30 days, and the stores selling on credit for the period more than 30 days is $7.7 \%$. Majority of the stores credit sales duration is less than 10 days. Those aspiring to start similar business can refer this fact and formulate their credit policies accordingly.

Table 9

Duration of credit purchase from the suppliers

\begin{tabular}{lll}
\hline Duration of credit purchase & Frequency & Valid percent \\
\hline 0-10 days & 25 & 64.1 \\
11-30 days & 11 & 28.2 \\
more than 30 days & 3 & 7.7 \\
\hline Total & 39 & 100 \\
\hline
\end{tabular}

Table 9 presents the duration of credit availed to the grocery shops by their respective suppliers or dealers. Out of 39 stores, 25 stores enjoy credit period of 0-10 days, 11 grocery shops enjoy credit facility for 11-30 days from their suppliers and only 3 stores have been availed credit of more than 30 days. One can notice that only 3 stores have been availed longer credit period by their suppliers. Discussions and studies are required to find out the factors that entail longer credit period by the suppliers. 
Table 10

Cause of damage of products

\begin{tabular}{lll}
\hline Cause of damage of products & Frequency & Valid percent \\
\hline Rotten & 5 & 12.8 \\
insects and rats & 23 & 59 \\
date expiry & 11 & 28.2 \\
\hline Total & 39 & 100 \\
\hline
\end{tabular}

Table 10 shows the causes of the damage of merchandise of the grocery shops. One of the major problems in grocery shops is the damage of the merchandise. The major cause of the damage of the goods can be attributed to pests and insects. Out of 39 grocery shops, 59\% of them claim that insect and pest are the leading cause of the damage. Similarly, 28.2\% stores said that expiry date is another prominent cause of damage. The least cause for damage is the goods being rotten. Out of 39 stores, 5 stores i.e. 12.8\% stated that goods are damaged on their own. It is alarming to notice that majority of the shop owner claim that insects and pests are the major cause of the damage. A key question that intrigues is that do the shop owners have proper training for merchandising? Like those of developed countries, does our government have pest controlling departments? If not the concerned authorities must take initiations.

Table 11

Correlation between average daily sales and raised capital correlation matrix $\quad \mathrm{NR}=39$

\begin{tabular}{llcc}
\hline & & Average daily sales & Raised capital \\
\hline Average daily sales & Pearson's correlation & 1 & \\
& Sig. (2-tailed) & & 1 \\
Raised capital & Pearson'scorrelation & $.595^{* *}$ & 1 \\
& Sig. (2-tailed) & 0.000 & \\
$* *$ Correlation is significant at the 0.01 level (2-tailed). &
\end{tabular}

Table 11 exhibits correlation between average daily sales and amount of capital invested in the business. The table shows that there is significant positive correlation between average daily sales and raised capital for $r=0.595$, calculated value of $p=0.000$ which is less than expected $\mathrm{p}$ value $(0.05)$. 
Table 12

Correlation between duration of credit purchase and duration of credit sales.

Correlations Matrix

$\mathrm{N}=39$

\begin{tabular}{llll}
\hline & & $\begin{array}{l}\text { Duration of credit } \\
\text { sales }\end{array}$ & $\begin{array}{l}\text { Duration of credit } \\
\text { purchase }\end{array}$ \\
\hline Duration of credit sales & $\begin{array}{l}\text { Pearson } \\
\text { Correlation } \\
\text { Sig. (2-tailed) }\end{array}$ & 1 & \\
$\begin{array}{l}\text { Duration of credit } \\
\text { purchase }\end{array}$ & $\begin{array}{l}\text { Pearson } \\
\text { Correlation }\end{array}$ & $0.844^{* *}$ & \\
& Sig. (2-tailed) & 0.000 & 1 \\
\hline
\end{tabular}

Notes. $* *$ Correlation is significant at the 0.01 level (2-tailed).

The table 12 shows correlation between duration of credit purchase and duration of credit sales. The table shows that there is significant positive correlation between "duration of credit purchase" and "duration of credit sales" because $r=0.844^{* *}$ and level of significance which the calculated $\mathrm{p}$ value $=0.000$ which is less than expected $\mathrm{p}$ value $=0.05$. Thus, statistically the null hypothesis is rejected. Interpretation -longer the duration of credit purchase, the longer will be the duration of credit sale or vice versa.

\section{Testing of Hypothesis}

$\mathrm{H}_{1}$ : The average daily sales revenue depends upon the amount of raised capital.

The tested model was; Average Daily Sales Revenue $=$ Constant $+b($ Raised Capital $)$

The linear regression analysis derived the following model summary.

Average Daily Sales Revenue $=5641.83+0.006$ Raised capital

$\mathrm{R}$ Square $=0.354$

Table 13

ANOVA 1

\begin{tabular}{lllllll}
\hline Model & & Sum of Squares & Df & Mean Square & F & Sig. \\
\hline 1 & Regression & 1457740659 & 1 & 1457740659 & 20.239 & 0.000 \\
& Residual & 2665002931 & 37 & 72027106.24 & & \\
& Total & 4122743590 & 38 & & &
\end{tabular}

a Dependent variable: average sales revenue

b Predictors: (constant), raised capital 
Interpretation. Sales revenue of retail stores is positively impacted by the raised capital. On average with an increase of Capital by NRs. 1, the average daily sales revenue will increase by Rs. 0.006 .

To test the above hypothesis, linear regression was used. The table 13 ANOVA 1 shows that the calculated $\mathrm{p}$. value $=0.000$, which is less than 0.05 . Thus, the model is significant.

$\mathrm{H}_{2}$ : Average daily sales revenue depends upon the age of business.

The tested model was; Average Daily Sales Revenue $=$ Constant $+b$ (Age of business) The linear regression analysis derived the following model summary.

Average Daily Sales Revenue $=5291.702+483.900$ (Age of business)

$\mathrm{R}$ square $=0.111$

Table 14

ANOVA 2

\begin{tabular}{lllllll}
\hline Model & & Sum of quares & Df & Mean square & F & Sig. \\
\hline 1 & Regression & 457775956.2 & 1 & 457775956.2 & 4.622 & .038 \\
& Residual & 3664967634 & 37 & 99053179.28 & & \\
& Total & 4122743590 & 38 & & &
\end{tabular}

a Dependent variable: average daily sales revenue

b Predictors: (Constant), age of business

Interpretation. Average Daily Sales Revenue is positively impacted by the age of business. With increase in the age of business by one year, the average daily sales revenue will increase by NRs. 483.900. The table ANOVA 2 shows that calculated $\mathrm{p}$ value $=0.038$, which is greater than the estimated $\mathrm{p}$. value $=0.05$. Thus, the model is insignificant.

$\mathrm{H}_{3}$ : There is no significant relationship between duration of credit purchase and duration of credit sales. To test this hypothesis, correlation test was used. The correlation statistics shows that $r=0.844^{* *}$ and the observed $p$ value $=0.000$ which is less than expected $p$ value $=0.05$

Therefore, null hypothesis is rejected, which means that there is significant relationship between the duration of credit sales and credit purchase.

\section{Findings \& Conclusion}

The study shows that out of 39 grocery shops located in Itahari, Nepal, 76.9\% stores were established in between 2061-2075 (Bikram Sambat, Nepali Calendar Year), followed by the next highest number $17.9 \%$ of stores established in between 2046-2060 B.S. The least number of grocery shops established before 2045 B.S and after 2076 B.S is 1 , which is $2.6 \%$. Majority of the grocery shops under this study were established during 2061 and 2075 B.S. Similarly, the 
data analysis revealed that average capital invested in the grocery shops is below or equal to NRs. 20,00,000/-. One shop's capital was found to be more than NRs. 40,00,000/- Furthermore, average daily sales of the grocery shops showed that out of 39 stores, 53.8\% stores' average daily sales are less or equal to NRs. $5,000 /$ - But the $23.1 \%$ of grocery shops' average daily sales is in the range of NRs. 5,000-10,000 or more than NRs. 10,000/-. Regarding the type of ownership of grocery shops the study shows that out of 39 grocery shops $97.4 \%$ of the shops are self owned or the business started by the persons themselves. Only 1 store, i.e. $2.6 \%$ of the shop is family inherited business. The findings related to the sales mode of the stores shows that out of 39 grocery shops $69.2 \%$ of the stores sell the goods in both cash and credit. Whereas; $28.2 \%$ stores sales mode is on cash. Credit sales and bad debt are related phenomenon. The bad debt loss of the grocery shops shows that out of 39 stores, only 2 stores' bad loss percentage is in between 5-10\%. Other 37 grocery shops bad debt loss rate is below $5 \%$. Seasonal sales comparison shows that volume of sales is high during summer. The findings reveal that out of 39 grocery shops $71.8 \%$ grocery shops stated that their sales volumes are high during the summer season; followed by the next highest number $15.4 \%$ stores stating that sales volume are high during the winter seasons.

Similarly, the shops having high sales indifferent to the seasons are $7.7 \%$. The analysis of the duration of credit sales of grocery shops shows that out of 39 grocery shops, 28 grocery shops' credit sales period is less or equal to 10 days. Similarly, 8 stores' credit sales duration is 11-30 days, and the stores selling on credit for the period more than 30 days is $7.7 \%$. The analysis of the duration of credit facility availed to the grocery shops by their respective suppliers or dealers shows that out of 39 stores, 25 stores enjoy credit period of 0-10 days, 11 grocery shops enjoy credit facility for 11-30 days from their suppliers and only 3 stores have been availed credit of more than 30 days. One can notice that only 3 stores have been availed longer credit period by their suppliers. The causes of the damage of goods attribute insects and pest as the major cause. Out of 39 grocery shops, $59 \%$ of them claim that insect and pest are the leading cause of the damage; followed by $28.2 \%$ stores' cause of damage is expiry date of the goods. Analysis of correlation between average daily sales and amount of capital invested in the business shows that there is significant positive correlation between average daily sales and raised capital for $r=0.595$, calculated value of $p=0.000$ which is less than expected $p$ value (0.05). Besides that correlation between duration of credit purchase and duration of credit sales shows that there is significant positive correlation between "duration of credit purchase" and "duration of credit sales" because $r=0.844^{* *}$ and level of significance which the calculated $p$ value $=0.000$ which is less than expected $p$ value $=0.05$. From the findings of the study it can be concluded that average daily sales of grocery stores is positively influenced by age of the store. Similarly, the amount of raised capital positively affects average daily sales and there is significant positive correlation between duration of credit purchase and duration of credit sales. 
References

Chron. (n.d.), Retrieved from https://smallbusiness.chron.com/difference-between-grocerystore-convenience-store-19023.html

European Union. (2003). Definition of micro, small and medium-sized enterprises. Summaries of EU legislations, EU, retrieved from http://europa.eu/legislation_summaries /enterprise/business_environment/n26026_en.htm

Educalingo. (n.d.), Retrived fromhttps://educalingo.com/en/dic-en/kirana

ILO. (2005). A Report on Micro and Small Enterprise Policy Review in Nepal. International Labour Organisation. Retrieved from http://www.ilo.org/wcmsp5/groups/public/@asia /@robangkok/@ilo-kathmandu/documents/publication/wcms_116688.pdf.

Industrial Enterprise Act 1992. Government of Nepal.

Karna,M., Rai, A., Karki, B., Karna, L., Rai, M., Adhikari, S., (2019). “A Study on Selection of Location by Retail Chain: Big Mart." International Journal of Research Granthaalayah, 7(1), 383-395. https://doi.org/10.5281/zenodo.2561093.

Kuijpers, D., Simmons, V., and Wamelen, J. V. (2019) Perspectives on retail and consumer goods available on : https://www.mckinsey.com/industries/retail/our-insights/revivinggrocery-retail-six-imperatives [Date accessed: 16, December, 2019].

Samriddhi Foundation \& FNCCI, (2013). The Economic Hazard of Bandh in Nepal. Retrieved from livablenepal.org.

The Government of Japan (2013). Small and Medium Enterprise Agency, The Government of Japan, Retrieved from http://www.chusho.meti.go.jp/sme_english/outline/08/01_01. html.

The Kathmandu Post, (2018). Retrieved from https://kathmandupost.com/money /2018/01/20/as-traditional-retail-shops-flounder-department-stores-thrives-in-east.

The Kathmandu Post, (2019). Retrieved from https://kathmandupost.com/money /2019/03/04/online-grocery-shopping-gaining-popularity-in-nepal. 